\title{
An Evaluation of Grazing Intensity Influences on Califor- nia Annual Range
}

\section{R.E. ROSILRE}

\section{Abstract}

Influences of grazing intensity on species composition and herbage production of grass-woodland and improved grassland subtypes of annual range were evaluated over a 5-year period in coastal northern California using 3 grazing treatments (100, 150, and $200 \%$ of moderate stocking). Herbage utilization did not differ significantly between the 2 subtypes but averaged 42,52 , and $69 \%$ for the respective treatments. Plant species and production responses differed significantly between woodland and grassland subtypes. On woodland, ripgut brome (Bromus rigidus Roth.)' and wild oats (Avena barbata Brot. and A. fatua L.) were most sensitive to grazing intensity while wild barley (Hordewm leporinwm Link. and H. hystrix Roth.) and annual fescue (Festuca dertonensis (all.) Asch. and Graebn. and $F$. megalure Nutt.) were least sensitive. On improved grassland, subterranean clover (Trifolium subterraneum L.) increased and soft chess (Bromus molis L.) decreased with increasing grazing intensity. Soft chess remained most plentiful on woodland range under heaviest graxing and it continued to be a major species under heavy grazing of grassland, demonstrating tolerance to grazing intensity. Filaree (Erodium cicutarium (L.) L'Her. and $E$. botrys (Cav.) Bertol.) declined on woodland but increased on grassiand as grazing intensined. Peak standing crop was not significantly affected by grazing intensity on woodland range but was greatest at $150 \%$ of moderate stocking and lowest at $200 \%$ of moderate stocking on grassland range. Decline in grassland herbage yield under heaviest grazing was due to reduction of soft chess which was displaced by subterranean clover. Effects of grazing intensity on range composition and productivity were confounded by innute differences in ranges and yearly weather patterns. Herbage production was impacted more by annual growing conditions than by graxing regimens, but there was no correlation between total annual precipitation and peak standing crop.

Key Words: grazing intensity, annual range, botanical composition, herbage yield

California annual range covers approximately 10 million hectares. It varies from open grassland dominated by introduced annual grasses and forbs to grass-woodland and chaparral with an herbacous understory. Much of the California annual type can be or has been improved by fertilization (Bentley et al. 1958, Jones 1963, Jones 1974) and seeding to legumes (Williams et al. 1956, Murphy et al. 1973). Although grazing management has been recognized as critical to the success of these improvements, it usually has been studied secondarily and incidental to them. Grazing management has been investigated frequently on unimproved annual range, mostly in relation to general plant reaction (Pitt and Heady 1979) or from perspectives of yearly fluctuation (Pitt and Heady 1978), genetics (Marshall and Jain 1969), seedling establishment (Bartolome 1979), and advancement through the growing season (Heady 1958).

The current appraisal of grazing intensity influences on range

St: If
tic Special thanks are given A.H. Murphy, superintendent, Hopland Field Station;
Shu Geng, biometrician, California Agr. Exp. Sta., for statistical assistance and to
M.P. McClaren, Ph.D. candidate, and H.F. Heady, range manager/ecologist, Cali-
fornia Agr. Exp. Sta., for reading the manuscript and offering many useful sugges-
tions. The aid of D.F. Gilman, associate professor of agronomy, Tarleton State
University, in revision of the manuscript was especially appreciated.
Study supported as Hatch Project 3992 .
Manuscript accepted 25 September 1986 .

Plant nomenclature from Munz and Keck(1973). communities accompanied evaluations of sheep performance and nutritional value of sheep diets during a grazing trial on annual grass-woodland and improved annual grassland range in coastal northern California (Rosiere and Torell 1985). The objectives of this study were to determine species composition, peak standing crop, utilization, and residue responses to grazing intensity.

\section{Materials and Methods}

\section{Study Site}

This investigation was carried out from 1979-1984 in coastal northern California on the University of California Hopland Field Station in Mendocino County $(160 \mathrm{~km}$ north of San Francisco Bay; 64 km inland) within the Pacific Coast Mountain Range. The precipitation-determined growing season in this region of Mediterranean climate lasts about 6 months (November to April; but may commence in October). Annual precipitation averages $90 \mathrm{~cm}$ but varied during duration of the study (Table 1 ).

Table 1. Total precipitation (cm), precipitation received by 20 November (cm) $)^{1}$ and date of first germinating rain for growth season years (July-June) 1979 to 1984 at Hopland Field Station, Califomia.

\begin{tabular}{lccl}
\hline \hline Growing season & $\begin{array}{c}\text { Total } \\
\text { precipitation }\end{array}$ & $\begin{array}{c}\text { Precipitation by } \\
\text { 20 November }\end{array}$ & $\begin{array}{l}\text { Date, } \\
\text { first rain }\end{array}$ \\
\hline $1979-1980$ & 109.3 & 26.8 (ave.) & 25 September \\
$1980-1981$ & 67.6 & 4.6 (dry) & 17 September \\
$1981-1982$ & 138.0 & 35.3 (wet) & 25 September \\
$1982-1983$ & 171.9 & 22.6 (ave.) & 16 September \\
$1983-1984$ & 103.8 & 37.8 (wet) & 20 August \\
\hline
\end{tabular}

'Date most correlated with herbage production (Murphy 1970).

Two forms of annual range were investigated: (1) improved annual grassland composed of native and naturalized annual grasses and forbs overseeded to subterranean clover and, (2) annual grass-oak woodland, a mosaic of annual grassland understory with an overstory of blue oak (Quercus douglasii H.\&A.), interior live oak ( $Q$. wislizenii A. DC.) and madrone (Arbutus menziesii Pursh.) and scattered sclerophyllus shrubs such as manzanita (Arctostaphylos spp. Adans.) and chamise (Adenostoma fasciculatum H.\&A.).

Improved range was established by overseeding Mount Barker and Woogenellup cultivars of subterranean clover $(22.4 \mathrm{~kg}$ seed $/ \mathrm{ha})$ and applying elemental sulfur $(12 \mathrm{k} / \mathrm{ha})$ and triple superphosphate (56 kg/ha; $11.3 \mathrm{~kg} \mathrm{P/ha).} \mathrm{In} \mathrm{fall,} 1980$ and 1983, improved range was top-dressed with single superphosphate $(168 \mathrm{~kg} / \mathrm{ha} ; 14.8 \mathrm{~kg}$ P/ha). Grass-woodland ranges were developed in 1961. They were managed since then at stocking rates similar to those employed in the present experiment (Pitt and Heady 1979).

Soils of woodland range were Josephine (Typic Haploxerult)2, Sutherlin (Aquic Haploxeralf), Laughlin (Ultic Haploxeroll) and Los Gatos (Typic Argixeroll). These soils were all clay loams; usually shallow, often gravelly. Grassland soils were the Soquel (Cumulic Haploxeroll) and Pleasanton (Mollic Haploxeralf) series which were both deep alluvial clay loams.

\section{Experimental Procedures}

Both range subtypes were evaluated at grazing intensities 100 ,

${ }^{2}$ Soil classification follows Soil Survey Staff (1975). 
Table 2. Species composition (\%) of annual grasu-woodland range grazed continuoudy at 3 grazing intenalties over 5 yearu in constal northern California.

\begin{tabular}{|c|c|c|c|c|c|c|c|c|c|c|c|c|c|c|c|}
\hline \multirow[b]{3}{*}{ Species } & \multicolumn{14}{|c|}{$\begin{array}{c}\text { Range (\% of Moderate Use) } \\
\text { Year }\end{array}$} & \\
\hline & \multicolumn{5}{|c|}{ S3 (100\%) } & \multicolumn{5}{|c|}{ S1 (150\%) } & \multicolumn{5}{|c|}{ D1 (200\%) } \\
\hline & 1979 & 1980 & 1981 & 1982 & 1983 & $\overline{1979}$ & 1980 & 1981 & 1982 & 1983 & 1979 & 1980 & 1981 & 1982 & 1983 \\
\hline Aira caryophyllea & 4 & 5 & 10 & 19 & 23 & 10 & 18 & 26 & 31 & 36 & 6 & 7 & 6 & 2 & 6 \\
\hline Avena barbata / fatua & 10 & 13 & 7 & 9 & 6 & 5 & 2 & 1 & 1 & 0 & 3 & 4 & 2 & 2 & 1 \\
\hline Bromus mollis & 36 & 38 & 27 & 28 & 34 & 40 & 37 & 33 & 26 & 30 & 61 & 60 & 52 & 49 & 41 \\
\hline Bromus rigidus & 14 & 7 & 10 & 4 & 3 & 10 & 2 & 5 & 3 & 2 & 4 & 1 & 2 & 1 & 1 \\
\hline Bromus rubens & 1 & 2 & 1 & $\mathbf{T}$ & 2 & 4 & 8 & 3 & 1 & 1 & $\mathbf{T}$ & $\mathbf{0}$ & $\mathbf{0}$ & $\mathbf{0}$ & 1 \\
\hline Elymus caput-medusae & 2 & 4 & 7 & 1 & 1 & $i$ & $\mathrm{~T}$ & 0 & 0 & 0 & 0 & 0 & $\mathbf{T}$ & 0 & 0 \\
\hline Festuca spp. & 2 & 1 & 3 & 2 & 5 & $T$ & $T$ & 0 & $\mathbf{T}$ & 1 & 2 & 13 & 13 & 12 & 27 \\
\hline Hordeum spp." & $\mathrm{T}$ & 1 & 1 & $\mathbf{T}$ & $\mathrm{T}$ & $T$ & $T$ & 1 & 1 & 0 & 5 & 2 & 6 & $\mathbf{T}$ & $\mathbf{T}$ \\
\hline Misc. annual Gramineae & $\mathbf{T}$ & 5 & 1 & 5 & 3 & $T$ & 3 & $\mathbf{T}$ & 0 & 5 & 2 & 1 & 4 & 2 & 2 \\
\hline Perennial Gramineae & $\mathbf{T}$ & $\mathbf{T}$ & $i$ & $\mathbf{T}$ & 0 & $T$ & 0 & 0 & 0 & 0 & 3 & $i$ & $\mathbf{T}$ & 0 & 0 \\
\hline Erodium spp. & 6 & 12 & 16 & 5 & 7 & 7 & 17 & 11 & 6 & 5 & $\mathbf{T}$ & 2 & $T$ & 1 & 1 \\
\hline Iris macrosiphon & 0 & 0 & 0 & 1 & 1 & 0 & 0 & 0 & 1 & $\mathbf{T}$ & 0 & 0 & 0 & 0 & 0 \\
\hline Lupinus spp. & 3 & $\mathbf{T}$ & 2 & 2 & $\mathrm{~T}$ & 0 & $\mathrm{~T}$ & 1 & 0 & $\mathrm{~T}$ & $\mathbf{0}$ & 0 & 0 & $\mathbf{T}$ & 0 \\
\hline Medicago hispida & 2 & 0 & 0 & 0 & 0 & $\mathbf{T}$ & 0 & 0 & 0 & 0 & 1 & 0 & 0 & 0 & 0 \\
\hline & 3 & 2 & 4 & 7 & 4 & 12 & 2 & 8 & 8 & 9 & $\mathbf{T}$ & 2 & 2 & 6 & 2 \\
\hline Misc. annual forbs & 17 & 10 & 10 & 17 & 11 & 11 & 11 & 11 & 22 & 11 & 13 & 7 & 13 & 24 & 18 \\
\hline
\end{tabular}

Primarily H. leporinum and H. hystrix.

briza minor, Bromus spp. Cynosurus echinatus, Gastridium ventricosum, Poa annua.

'Stipa pulchra except for $1 \%$ Sitanion jubatum in D1 in 1979.

Baeria chrysostoma, Brodiaea spp. Carduus pycnocephalus Daucus pusillus, Geranium spp., Lepidium spp., Lotus spp.

$T=$ Trace (less than 1\%).

150 , and $200 \%$ of moderate use under continuous yearlong grazing by flocks of crossbred-wool ewes. For the 100, 150, and $200 \%$ moderate use treatments, grass-woodland ranges were Pastures S3 (21.9 ha), S1 (15.4 ha), and D1 (2.5 ha) grazed on average over the 5 -year period by 11,13 , and 8 ewes; while improved annual grassland range units were Paddocks LM1 (1.5 ha), LM 3 (1.0 ha), and LM 2 ( $8 \mathrm{ha})$, each grazed by 8 ewes. Mean stocking rates of woodland and grassland range for the respective grazing treatments were .6, 1.8, and 3.1 and 5.3, 8.0, and 10.0 ewes/grazable ha, plus their spring-born lambs for 3 months and 1 ram for 2 months. In all years except 1981, periodic addition of sheep to improved grassland was necessary in early portions of the growing season to reduce shading of subterranean clover. Put and take stocking was consistent with the 3 grazing intensities.

Species composition of pastures was determined at peak standing crop (varied from last week of April to second week of May depending on the year) using the step point procedure (Evans and Love 1957). Herbage production was measured as peak standing crop and utilization was determined prior to first fall germinating rains by the formula: 1 - (fall residue $\div$ peak standing crop). Standing crop and residue or mulch (Hedrick 1948) were measured by clipping (ground level) and weighing biomass from $.09-\mathrm{m}^{2}$ plots in 10 randomly chosen locations within stratified perimeters representing key areas and range sites. Wire cages were used to protect herbage for peak standing crop.

Effects of range subtype, stocking rate, and yearly growing conditions on herbage production, species composition, utilization and residue were evaluated by factorial analysis of variance (Steel and Torrie 1980). Subtypes and grazing intensities were viewed as fixed and years as random effects (repeated measures over time). Relationships between peak standing crop and total yearly precipitation, precipitation by 20 November, quantity of mulch present at onset of growing season, and percent herbage utilization the previous year were analyzed by simple linear correlation (Steel and Torrie 1980).

\section{Results and Discussion}

Botanical composition (Tables 2 and 3), peak standing crop, utilization, and residue (Table 4) varied significantly between grass-woodland and improved grassland range and among grazing intensities, years, and their interactions (Table 5).

Table 3. Species composition (\%) of improved annual grasaland range grazed continuously at 3 grazing intendities over 5 years in coastal northern Californin.

\begin{tabular}{|c|c|c|c|c|c|c|c|c|c|c|c|c|c|c|c|}
\hline \multirow[b]{3}{*}{ Species } & \multicolumn{14}{|c|}{$\begin{array}{c}\text { Range ( } \% \text { of Moderate Use) } \\
\text { Year }\end{array}$} & \\
\hline & \multicolumn{5}{|c|}{ LM1 $(100 \%)$} & \multicolumn{5}{|c|}{ LM3 (150\%) } & \multicolumn{5}{|c|}{ LM2 (200\%) } \\
\hline & 1979 & 1980 & 1981 & 1982 & 1983 & 1979 & 1980 & 1981 & 1982 & 1983 & 1979 & 1980 & 1981 & 1982 & 1983 \\
\hline Bromus mollis & 29 & 51 & 51 & 38 & 34 & 21 & 47 & 40 & 26 & 38 & 17 & 43 & 31 & 24 & 12 \\
\hline Elymus caput-medusae & 0 & 1 & 2 & 1 & 2 & 0 & $\mathbf{T}$ & $\mathbf{0}$ & 0 & 0 & 0 & 0 & 0 & 0 & 0 \\
\hline Festuca spp." & 1 & 10 & 0 & 1 & 8 & 3 & 15 & 4 & 3 & 3 & 8 & 7 & 3 & 4 & 6 \\
\hline Hordeum spp. & 3 & 20 & 17 & 13 & 3 & 9 & 15 & 21 & 12 & 7 & 8 & 14 & 10 & 5 & 1 \\
\hline Other annual Gramineae & 0 & 0 & 0 & 0 & $T$ & 1 & 0 & 0 & 0 & 0 & $\mathbf{T}$ & 0 & 0 & $\mathbf{T}$ & 0 \\
\hline Erodium spp. & 2 & 4 & 2 & 2 & 1 & 7 & 9 & 4 & 4 & 1 & 2 & 11 & 8 & 6 & 2 \\
\hline Trifolium subterraneum & 64 & 14 & 26 & 45 & 50 & 57 & 14 & 29 & 53 & 51 & 62 & 25 & 46 & 59 & 73 \\
\hline Other Trifolium spp. & 1 & $T$ & 0 & 0 & 0 & $T$ & 0 & 0 & $\mathbf{T}$ & 0 & 2 & $\mathbf{T}$ & 0 & $T$ & 0 \\
\hline Miscellancous forbs ${ }^{c}$ & $\mathbf{T}$ & $\mathbf{T}$ & 2 & 0 & 2 & 2 & 0 & 2 & 2 & $\mathbf{T}$ & 1 & $\mathbf{T}$ & 2 & 2 & 6 \\
\hline
\end{tabular}

Primarily $F$. megalura.

brimarily $\boldsymbol{H}$. leporinum and $\boldsymbol{H}$. hystrix.

'Primarily Siellaria media.

$\mathrm{T}=$ Trace (less than $1 \%$ ) 
Table 4. Peak standing crop (kg/ha) reddue (kg/ha; \%)" and utilization (\%) of annual grase-woodland range and improved annual grasaland range grazed continuously at 3 stocking rates over 5 years in coastul northern Californin.

\begin{tabular}{|c|c|c|c|c|c|c|c|c|c|c|c|c|c|c|c|c|c|c|}
\hline & \multicolumn{18}{|c|}{ Range (\% of Moderate Use) } \\
\hline & \multicolumn{18}{|c|}{ Woodland Range } \\
\hline & \multicolumn{6}{|c|}{ S3 (100\%) } & \multicolumn{6}{|c|}{ S1 (150\%) } & \multicolumn{6}{|c|}{ D1 $(200 \%)$} \\
\hline & 1979 & 1980 & 1981 & 1982 & 1983 & Mean & 1979 & 1980 & 1981 & 1982 & 1983 & Mean & 1979 & 1980 & 1981 & 1982 & 1983 & Mean \\
\hline $\begin{array}{l}\text { Peak standing crop } \\
\text { Residue }\end{array}$ & 2098 & 1281 & 1485 & 1420 & 2916 & 1840 & 1442 & 753 & 710 & 764 & 1410 & 1015 & 2034 & 1022 & 1776 & 1108 & 1819 & 1552 \\
\hline $\mathrm{kg} / \mathrm{ha}$ & 1442 & 872 & 936 & 699 & 947 & 979 & 1033 & 549 & 323 & 355 & 291 & 510 & 1625 & 409 & 430 & 291 & 237 & 598 \\
\hline$\%$ of standing crop & 68 & 68 & 63 & 49 & 32 & 53 & 72 & 73 & 45 & 46 & 21 & 50 & 80 & 40 & 24 & 26 & 13 & 39 \\
\hline \multirow[t]{4}{*}{ Utilization } & 31 & 32 & 37 & 51 & 67 & 44 & 28 & 27 & 55 & 53 & 79 & 49 & 20 & 60 & 76 & 74 & 87 & 63 \\
\hline & \multicolumn{18}{|c|}{ Grassland Range } \\
\hline & \multicolumn{6}{|c|}{ LM1 (100\%) } & \multicolumn{6}{|c|}{ LM3 (150\%) } & \multicolumn{6}{|c|}{ LM2 (200\%) } \\
\hline & 1979 & 1980 & 1981 & 1982 & 1983 & Mean & 1979 & 1980 & 1981 & 1982 & 1983 & Mean & 1979 & 1980 & 1981 & 1982 & 1983 & Mean \\
\hline $\begin{array}{l}\text { Peak standing crop } \\
\text { Residue }\end{array}$ & 3562 & 5058 & 4488 & 5144 & 4843 & 4619 & 2561 & 4864 & 4746 & 5962 & 7081 & 5041 & 2055 & 3993 & 4552 & 3702 & 3831 & 3627 \\
\hline $\mathbf{k g} / \mathrm{ha}$ & 2615 & 2626 & 3046 & 2970 & 2217 & 2695 & 1819 & 2131 & 2454 & 1873 & 1819 & 2019 & 1055 & 990 & 807 & 796 & 377 & 805 \\
\hline$\%$ of standing crop & 73 & 52 & 68 & 58 & 46 & 58 & 71 & 44 & 52 & 31 & 26 & 40 & 51 & 25 & 18 & 22 & 10 & 22 \\
\hline Utilization & 27 & 48 & 32 & 42 & 54 & 41 & 29 & 56 & 48 & 69 & 74 & 55 & 49 & 75 & 82 & 78 & 91 & 75 \\
\hline
\end{tabular}

"Prior to first fall germinating rain.

Table 5. Significance of main effects, interactions and first order reaponses in plant species, peak standing crop, mulch and utilization on grase-woodland and annual grasaland range grazed at 3 grazing intenaities for 5 years in coastal northern California.

\begin{tabular}{|c|c|c|c|c|c|c|c|c|c|c|c|c|}
\hline \multirow[b]{2}{*}{ Source of Variation } & \multicolumn{9}{|c|}{ Species } & \multirow{2}{*}{$\begin{array}{c}\text { Peak } \\
\text { standing } \\
\text { crop }\end{array}$} & \multirow[b]{2}{*}{ Mulch } & \multirow{2}{*}{$\begin{array}{l}\text { Utiliza- } \\
\text { tion }\end{array}$} \\
\hline & Ai ca & Av spp & Br mo & Br ri & $\mathrm{Br} \mathbf{r u}$ & Er spp & Fe spp & Ho spp & Tr su & & & \\
\hline Range Subtype (RS) & $* * *$ & $* * *$ & NS & ** & $* *$ & NS & NS & $* *$ & $* * *$ & $* * *$ & $* *$ & NS \\
\hline Grazing Intensity (GI) & $* * *$ & $* * *$ & NS & $* * *$ & $* *$ & $*$ & $* * *$ & NS & $* *$ & NS & $\omega *$ & $* *$ \\
\hline Year $(\mathbf{Y})$ & $* * *$ & $* * *$ & $* * *$ & $* * *$ & $* * *$ & $* * *$ & $* * *$ & $* * *$ & $* * *$ & $* * *$ & $* * *$ & $* * *$ \\
\hline$G I \times Y$ & $* * *$ & NS & $* *$ & NS & $* * *$ & NS & $* *$ & $*$ & $* *$ & $* * *$ & NS & NS \\
\hline \multicolumn{12}{|l|}{ GI within Woodland } & NS \\
\hline Linear & $* * *$ & $* * *$ & $* * *$ & $* * *$ & $* *$ & $* * *$ & $* *$ & $* *$ & & NS & $* * *$ & $* *$ \\
\hline Quadratic & $* * *$ & $* * *$ & $* * *$ & NS & $* *$ & $* *$ & $* *$ & $*$ & & NS & $\omega *$ & NS \\
\hline \multicolumn{13}{|l|}{ GI within Grassland } \\
\hline Linear & & & **** & & & $* *$ & NS & $*$ & $* * *$ & $* *$ & $* * *$ & $* * *$ \\
\hline Quadratic & & & NS & & & NS & NS & $* *$ & $* *$ & $* *$ & $\omega *$ & NS \\
\hline
\end{tabular}

"Aira caryophyllea (Ai ca), Avena species (Av spp), Bromus mollis (Br mo), Bromus rigidus (Br ri), Bromus rubens (Br ru), Erodium species (Er spp), Festuca species (Fe spp), Hordeum species (Ho ssp) and Trifolium subterraneaum (Tr su).

$*=p<1$.

$* *=P<.05$.

$* * *=P<005$

NS $=$ Nonsignificant .

\section{Species Composition}

Most species responded to grazing intensities across an array of growing conditions during the 5 years of study (Table 1). All species had highly significant year effects. Soft chess and wild barley were the only species not significantly influenced by grazing intensity across both range subtypes; filaree, ripgut, and wild oats were the only ones for which grazing intensity $X$ year interactions did not occur (Table 5).

Responses of species were most meaningful when evaluated on the 2 range subtypes separately because effects often varied between woodland and grassland (Fig. 1 and 2; Table 5). Soft chess decreased with increasing grazing intensity on grassland but not on woodland range. Ripgut brome and wild oats occurred only on woodland, where they decreased as grazing intensified. Filaree also declined on woodland but increased on improved grassland with higher stocking rates. Woodland populations of silver hairgrass (Aira caryophyllea L.) and red brome Bromus rubens $\mathrm{L}$.) were the greatest at $150 \%$ of moderate grazing and decreased to their lowest levels at $200 \%$ of moderate grazing. Annual fescue and barley species were least frequent on woodland at the intermediate stocking rate and were most common under heaviest grazing. On grassland, wild barley increased under $150 \%$ of moderate grazing to decline to its lowest frequency at 2 times moderate stocking. Popu-

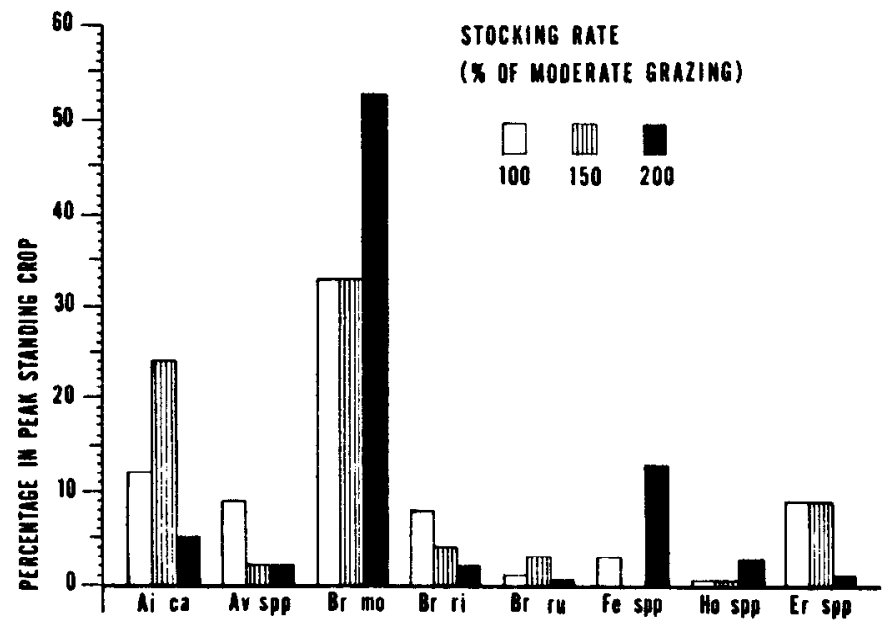

Fig. 1. Mean percentages (over 5 years) of 8 plant species (Aira caryophyllea [Ai ca] Avena species [Av spp], Bromus mollis [ $\mathrm{Br}$ mo], Bromus rigidus [ $\mathrm{Br}$ ri] Bromus rubens [ $\mathrm{Br} \mathrm{ru}$ ], Festuca species [ $\mathrm{Fe}$ spp] Hordeum species [Ho spp], and Erodium species [Er spp] at peak standing crop on annual grass-woodland ranges grazed continuously under 3 grazing intensities in coastal northern Califormia. 


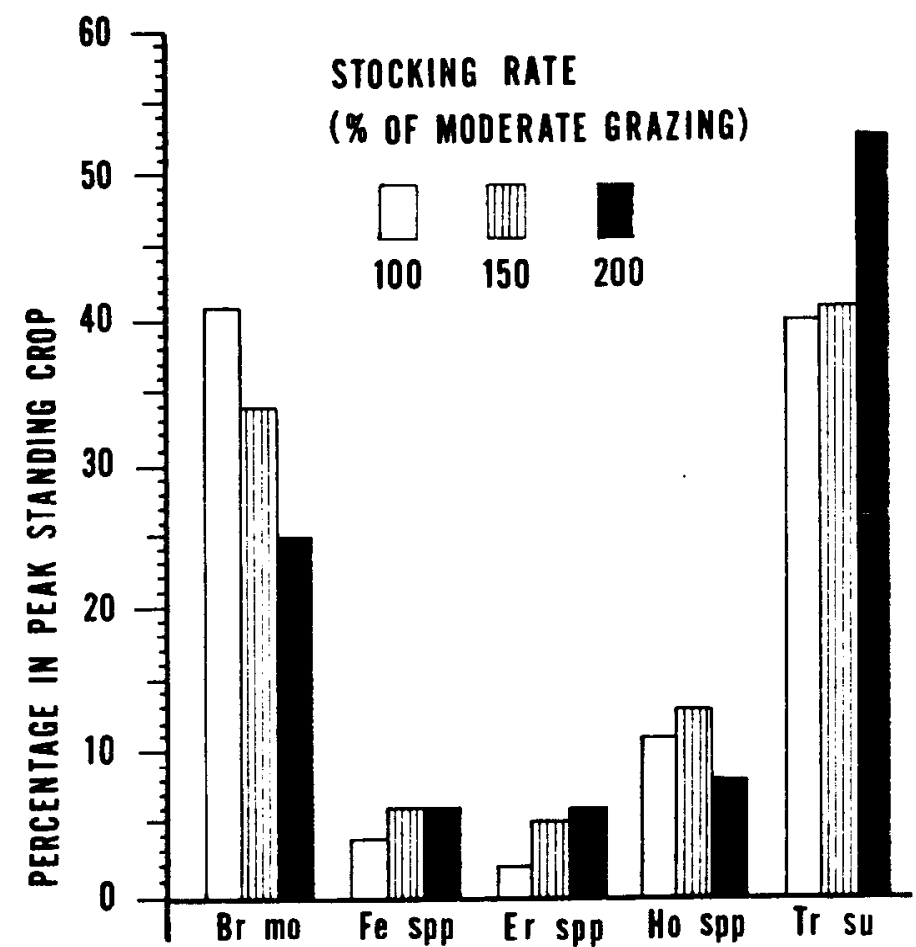

Fig. 2. Mean percentages (over years) of 5 plant species (Bromus mollis [ $\mathrm{Br}$ mo], Festuca species [Fe spp], Erodium species [Er spp], Hordeum species [Ho spp] and Trifolium subterraneum [tr su]), at peak standing crop on improved annual grassland ranges grazed continuously under 3 grazing intensities in coastal northern California.

lations of annual fescue did not differ among grazing intensities on grassland. Subterranean clover increased under increasing grazing intensities.

Species responses required careful interpretation as some species occurred exclusively on 1 range subtype while others were important on both subtypes (Tables 2 and 3 ). On woodland range ripgut was the most sensitive to grazing intensity, followed by wild oats. Soft chess reacted similarly but was tolerant to grazing at a spectrum of stocking rates. Though soft chess frequency was less at the end than beginning of the study on all woodland ranges, it remained most plentiful under heaviest grazing. General decline of soft chess populations on woodland over the study period was likely due to growing conditions reflected in significant year effects. On improved grassland, soft chess was least common under heaviest grazing but even then it remained a major component of the vegetation.

Decline in soft chess and secondary grasses under heavier defoliation benefitted subterranean clover on grassland range (Table 3 ). This relationship had important management implications: populations of subterranean clover were increased by raising stocking rates. Similar findings were reported by other workers (Suckling 1975, Fitzgerald 1976, Sharrow et al. 1981) and were attributed to competitive advantage of subclover as a function of adaptations such as location of flowers near the soil surface, burial of seed and prostrate growth form (Rossiter 1966). Heavy grazing was especially beneficial to subclover when put and take stocking was practiced to reduce grass competition early in the growing season.

Filaree fell into 2 response categories because it, like ripgut and wild oats, decreased with heavier grazing on woodland but increased with subterranean clover under heavier stocking rates on grassland. This difference may have resulted from selective grazing pressure. Sheep may have grazed filaree more intensely on woodland ranges because they could exercise their preference for forbs (Stoddart et al. 1975) most readily from this species; whereas on grassland, subterranean clover was more available if not more palatable. Differences in competition for factors such as sunlight or soil moisture may also have been involved in contrasting responses of filaree between the 2 range subtypes.

Stocking rate reactions in the present trial coincided with those reported by several authors. On protected foothill range, Talbot and Biswell (1942) documented increases of ripgut, wild oats, and soft chess and a decrease in filaree. Bentley and Talbot (1951) quantified essentially the same shifts as grazing intensity declined from heavy to light, but filaree was greater under moderate than close grazing. Sampson et al. (1951) related these changes to successional response.

Heady (1956a, 1977) classified annual plants according to succession hierarchy with a ripgut/soft chess/ wild oats complex as climax. Ripgut and wild oats were not major species in the present experiment, but detection of grazing reactions similar to those under conditions where they were community dominants (Heady 1958) was further evidence that these species are relatively sensitive to heavy grazing.

The progression from most to least sensitive species by ripgut, wild oats, soft chess, and filaree in this trial was similar to that described by Biswell (1956), where annual communities progressed from forbs to soft chess to wild oats to ripgut under protection following heavy grazing. This sequence was perhaps partially disputed by the Heady (1956a) classification of all 3 grasses as decreasers but neither author was specific as to range site.

Burcham (1957) outlined retrogression of the annual type from a first stage of wild oats (with some ripgut and less soft chess) to mostly soft chess at moderate grazing. Deterioration led to filaree, wild barley, annual fescue, etc., and then to a third sere of red brome, wild barley, silver hairgrass, and various forbs. A similar pattern occurred during the current study where red brome and silver hairgrass first increased under heavier grazing and then decreased under heaviest intensity. These seemed to be responses typical of increaser species. Red brome was classified once by Heady (1956a) as an increaser and later (Heady 1977) as a climax species.

Wild barley and annual fescue reactions were variable and difficult to assess. These species tended to increase with successively heavier grazing, with wild barley being more sensitive than annual fescue to heavy use. This latter finding contradicted the range degeneration sequence of Burcham (1957) but confirmed Bentley and Talbot (1951) who measured increases in fescue and decreases in barley on closely grazed swale sites. Wild barley was observed to first increase and then decline with progressively heavier grazing on subclover pastures in Australia (Rossieter 1966, Fitzgerald 1976).

\section{Herbege Production and Residue}

Peak standing crop on woodland range was not significantly affected by grazing intensity. Grassland standing crop was greatest under $150 \%$ of moderate use and lowest under $200 \%$ of moderate use (Tables 4 and 5). Utilization increased linearily with increasing intensities of grazing on both range subtypes. Utilization did not differ between the subtypes but averaged 42,52 , and $69 \%$ for 100 , 150 , and $200 \%$ of moderate grazing, respectively. Herbage residue decreased concommitantly with increasing utilization but not in direct relation (Tables 4 and 5).

A correlation between herbage residue and peak standing crop existed on grassland but not on woodland (Table 6); when calculated over both range subtypes there was a strong relationship between these 2 variables $\left(r^{2}=.74\right)$. There was no association between standing crop and percent herbage utilization. Years had highly significant effects on peak standing crop, herbage residue and utilization.

Heavier grazing of improved grassland range and consequent increase in subterranean clover was at the expense of total herbage production. Peak standing crop at 2 times moderate grazing was about three-fourths of herbage biomass produced at moderate and 
Table 6. Linent correlation coefricients between peak standing crop (PSC) and total annual precipitation (AP), precipitation recelved by 20 November (NP), percent herbage utilization the previous year (HU) and quantity of residue, mulch, present at beginning of crowing season (QR) on annual grase-woodland range (WR) and improved annual grasaland range (GR) in coastal northern Callfomia during growing seasons from 1979-1983.

\begin{tabular}{lcccc}
\hline \hline PSC & AP & NP & HU & QR \\
\hline WR & $-.12 \mathrm{NS}$ & $.49^{* *}$ & $.35 \mathrm{NS}$ & $-.16 \mathrm{NS}$ \\
GR & $.11 \mathrm{NS}$ & $.05 \mathrm{NS}$ & $-.22 \mathrm{NS}$ & $.52^{* *}$ \\
Overall1 & $.02 \mathrm{NS}$ & $.10 \mathrm{NS}$ & $.05 \mathrm{NS}$ & $.86^{* *}$ \\
\hline
\end{tabular}

${ }^{1}$ Three woodland and 3 grassland ranges over 5 growing seasons for precipitation and over 4 growing seasons for utilization and mulch measurements. $* *=P<01$

NS $=$ Nonsignificant

one and a half times moderate rates. Shifts in species composition on woodland range did not result in changes in amount of herbage produced. This was not explained but may have been partly a consequence of more summer annuals, notably turkey mullein (Eremocarpus setigerus (Hook.) Benth.), growing on the 2 heavier grazed ranges. Biswell (1956) also reported greater incidence of turkey mullein with heavy grazing.

Failure to detect influence of grazing intensity on peak standing crop in the grass-woodland subtype corroborated earlier studies. Pitt and Heady (1979) found identical patterns of standing crop response under 100,150 , and $200 \%$ moderate grazing intensities in a 4year trial which was conducted on some of the same ranges used in the current experiment. On annual range in the Sierra foothills, Bentley and Talbot (1951) reported higher herbage yield with light and moderate grazing than with close grazing. However, they discovered that herbage production was influenced substantially only at heavy use. Their investigations employed seasonal rather than yearlong use so grazing was probably more intense during plant growth than in the Hopland projects. Pitt and Heady (1979) concluded that differences in herbage production attributable to grazing intensities ranging from moderate to heavy were unimportant in management since yearly differences were greater within stocking rates than among them.

The dominant effect of yearly variability in growing conditions was obvious in the present 5-year investigation. Years were the only source of variation which affected all species and herbage production/utilization features (Table 5). Also, the magnitude of influence appeared greater for yearly effects. The largest difference in peak standing crop among grazing intensities was the $25 \%$ reduction in herbage yield on improved grassland range under the heaviest grazing treatment. By comparison, the mean difference between highest and lowest peak standing crop among years within grassland stocking treatments was $51 \%$ (from Table 4). Mean difference among years on grass-woodland range was $48 \%$.

Although annual fluctuation in growing conditions was the major variable that influenced herbage production, this was apparently not due to differences in total precipitation because there was no correlation between this factor and peak standing crop (Table 6). Fall precipitation was positively related to herbage production on woodland range. These findings were consistent with those reported by Murphy (1970). Pitt and Heady (1978) substantiated negative correlations between standing crop and amount of rainfall in early to mid-spring, but Duncan and Woodmansee (1975) found no meaningful associations between total precipitation and herbage yield.

Effects of utilization were some of the most direct influences in this investigation. Utilization was the only variable in which grazing intensity did not interact with range subtype (Table 5). Most grazing intensity experiments on annual range have focused primarily on manipulation to retain various amounts of residue (mulch) after grazing (Heady 1977). Importance of mulch in the annual type was recognized early on by rangemen (Talbot et al. 1939 , Young 1945) and guidelines have been periodically revised (Clawson et al. 1982). While mulch is currently the best or most accepted criterion for proper grazing management, it could not be used in the current trial as a direct measure of grazing intensity because it was possible to have more residual herbage on a heavier grazed range if that range had produced more total biomass (e.g., Range S1 vs. D1; Table 4). Mulch was a function of both grazing intensity and herbage yield but percent utilization was a result of stocking rate and served as a gauge to the intensity of defoliation.

A cause / effect relationship between quantity of mulch and herbage production as demonstrated by Heady (1956b) was not demonstrated by this or the Pitt and Heady (1979) trial. Importance of differences among range sites and individual ranges in setting mulch standards was shown. For example, Bartolome et al. (1980) determined that $840 \mathrm{~kg} / \mathrm{ha}$ of mulch was proper for annual range (unimproved) in the $40-100 \mathrm{~cm}$ precipitation belt, but in the current study there was no significant effect on herbage yield among grazing intensities that left from 510 to $979 \mathrm{~kg}$ of mulch/ha. Perhaps innate differences in production potential among ranges negated influences of mulch or perhaps mulch recommendations were too general. Because ranges are unique combinations of biological and physical features, proper amounts of mulch could vary even among proximate grazing units.

Differences among pastures and growing conditions should be considered in evaluating results of defoliation. While grazing intensity had limited influence on herbage yield from unimproved annual range, effects might have been confounded or masked by yearly variation in herbage production, natural fluctuation in species composition, or diversity among ranges.

\section{Conclusions}

Subterranean clover increases under heavy grazing of fertilized annual grassland due to reduced competition with grasses. Increase in subterranean clover is primarily at expense of soft chess and results in reduced herbage production and subsequent mulch accumulation. For northern California, a stocking rate of 2 animal units/ha is recommended to maintain an optimum stand of subclover in a mixture of annual grasses and forbs.

Soft chess is adapted to an array of grazing intensities in the annual type. Stocking rates as high as .6 and 2 animal units/ha on woodland and improved grassland, respectively, allow maintenance of soft chess populations.

On annual range, some species fit conventional ecological groupings (e.g., ripgut and wild oats are classic "decreasers") while others do not (e.g., annual fescue and wild barley).

Herbage production on grass-woodland range is not substantially influenced by intensities of grazing that are reasonable for livestock production. Such influence is small compared to natural factors like site potential and weather conditions, but total precipitation is of minor importance. In the northern Coast Range, stocking rates from .1 to .6 animal unit/ha produce similar yields of herbage, but lower rates favor larger plant species.

\section{Literature Cited}

Bartolome, J.W. 1979. Germination and seedling establishment in California annual grassland. J. Ecology 67:273-281.

Bartolome, J.W., M.C. Stroud, and H.F. Heady. 1980. Influence of natural mulch on forage production on differing California annual range sites. J. Range Manage. 33:4-8.

Bentley, J.R., and M.W. Talbot. 1951. Efficient use of annual plants on cattle ranges in the California foothills. USDA Circular No. 870. Washington, D.C.

Bentley, J.R., L.R. Green, and K.A. Wagnon. 1958. Herbage production and grazing capacity on annual plant range pastures fertilized with sulfur. J. Range Manage. 11:133-140.

Biswell, H.H. 1956. Ecology of California grasslands. J. Range Manage. 9:19-24. 
Burcham, L.T. 1957. California rangeland-an historico-ecological study of the range resource of California. California Division of Forestry, Sacramento.

Clawson, W.J., N.K. McDougald, and D.A. Duncan. 1982. Guidelines for residue management on annual range. California Agr. Ext. Leaflet 21327.

Duncan, D.A., and R.G. Woodmansee. 1975. Forecasting forage yield from precipitation in California's annual rangeland. J. Range Manage. 28:327-329.

Evans, R.A., and R.M. Love. 1957. The step-point method of sampling-a practical tool in range research. J. Range Manage. 10:208-212.

Fitzgerald, R.D. 1976. Effect of stocking rate, lambing time and pasture management in wool and lamb production on annual subterranean clover pasture. Australian J. Agr. Res. 27:261-275.

Heady, H.F. 1956a. Evaluation and measurement of the California annual type. J. Range Manage. 9:25-27.

Heady, H.F. 1956. Changes in a California annual plant community induced by manipulation of natural mulch. Ecology 37:798-812.

Heady, H.F. 1958. Vegetational changes in the California annual type. Ecology 39:402-416.

Heady, H.F. 1977. Valley grassland. In: Barbour, M.G. and J. Major (eds.). Terrestrial Vegetation of California. John Wiley \& Sons, Inc., New York.

Hedrick, D.W. 1948. The mulch layer of California annual ranges. J. Range Manage. 1:22-25.

Jones, M.B. 1963. Yield, percent nitrogen, and total nitrogen uptake of various California annual grassland species fertilized with increasing rates of nitrogen. Agron. J. 55:254-257.

Jones, M.B. 1974. Fertilization of annual grasslands of California and Oregon. In: Mays, D. (ed.). Forage Fertilization. Amer. Soc. Agron. Madison, Wis.

Marshall, D.R., and S.K. Jain. 1969. Interference in pure and mixed populations of Avena fatua and A. barbata. J. Ecology 57:251-270.

Munz, P.A., and D.D. Keck. 1973. A California flora and supplement. Univ. California Press, Berkeley.

Murphy, A.H. 1970. Predicted forage yield based on fall precipitation in California annual grasslands. J. Range Manage. 23:363-365.
Murphy, A.H., M.B. Jones, J.W. Clawson, and J.E. Street. 1973. Management of clovers on California annual grasslands. California Agr. Ext. Circular 564.

Pitt, M.D., and H.F. Heady. 1978. Responses of annual vegetation to temperature and rainfall patterns in northern California. Ecology 59:336-350.

Pitt, M.D., and H.F. Heady. 1979. The effects of grazing intensity on annual vegetation. J. Range Manage. 32:109-114.

Rosiere, R.E., and D.T. Torell. 1985. Nutritive value of sheep diets from coastal California annual range. Hilgardia 53:1-19.

Roseiter, R.C. 1966. Ecology of the Mediterranean annual-type pasture. In: Norman, A.G. (ed.). Advances in Agronomy 18:1-56.

Sampson, A.W., A. Chase, and W.D. Hedrick. 1951. California grasslands and range forage grasses. California Agr. Exp. Sta. Bull. 724.

Sharrow, S.H., W.C. Krueger, and F.0. Thetford, Jr. 1981. Effects of stocking rate on sheep and hill pasture performance. J. Anim. Sci. 52:210-217.

Soil Survey Staff. 1975. Soil taxonomy-a basic system of soil classification for making and interpreting soil surveys. Agr. handbook No. 436. USDA Soil Conservation Service, Washington, D.C.

Steel, R.G., and J.H. Torrie. 1980. Principles and procedures of statistics-a Biometrical approach (2nd ed.) McGraw-Hill, Inc.

Stoddart, L.A., A.D., Smith, and T.W. Box. 1975. Range management. McGraw-Hill, Inc.

Suckling, F.E.T. 1975. Pasture management trials on unploughable hill country at Te Awa. III. Results for 1959-1969. New Zealand J. Exp. Agr. 3:351-436.

Talbot, M.W., and H.H. Biswell. 1942. The forage crop and its management. In: Hutchinson, C.B., and E.I. Koitok (eds.). The San Joaquin Experimental Range. California Agr. Exp. Sta. Bull. 663.

Talbot, M.W., H.H. Biswell, and A.L. Hormay. 1939. Fluctuations in the annual vegetation of California. Ecology 20:394-402.

Young, V.A. 1945. Proper grazing use of southern California annual type ranges. USDA Soil Conserv. Serv. Portland, Ore.

Williams, W.A., R.M. Love, and J.P. Conrad. 1956. Range improvement in California by seeding annual clovers, fertilization and grazing management. J. Range Manage. 9:28-33.

\section{Deadline Dates for Advertising and Announcements \\ Journal of Range Management \\ March Issue - February 5, 1987 \\ May Issue-April 6, 1987 \\ July Issue-June 8, 1987 \\ September Issue-August 10, 1987 \\ November Issue-October 8, 1987 \\ Rangelands \\ April Issue - March 10, 1987 \\ June Issue - May 7, 1987 \\ August Issue-July 8, 1987 \\ October Issue-September 8, 1987 \\ December Issue- November 4, 1987}

Copy must arrive by the above dates. For 1 -time advertising that requires cover space or an entire page, an insertion order must arrive two (2) weeks prior to the above dates.

Art copy requiring color separations not furnished by the advertiser should arrive one (I) week prior to the above dates. 